\section{DIGITAL COMMONS \\ @ UNIVERSITY OF SOUTH FLORIDA}

\section{ABO: Interactive Journal for Women in the Arts, 1640-1830}

Volume 2

Issue 1 Volume 2.1 (Spring 2012): Open Access

Article 18

2012

\title{
The Experience of Domestic Service for Women in Early Modern London, ed. by Paula Humfrey
}

Marisa Iglesias

University of South Florida, miglesia@mail.usf.edu

Follow this and additional works at: https://digitalcommons.usf.edu/abo

Part of the Dramatic Literature, Criticism and Theory Commons, Educational Methods Commons, Feminist, Gender, and Sexuality Studies Commons, and the Literature in English, British Isles Commons

\section{Recommended Citation}

Iglesias, Marisa (2012) "The Experience of Domestic Service for Women in Early Modern London, ed. by Paula Humfrey," ABO: Interactive Journal for Women in the Arts, 1640-1830: Vol.2: Iss.1, Article 18. http://dx.doi.org/10.5038/2157-7129.2.1.17

Available at: https://digitalcommons.usf.edu/abo/vol2/iss1/18

This Reviews is brought to you for free and open access by Digital Commons @ University of South Florida. It has been accepted for inclusion in ABO: Interactive Journal for Women in the Arts, 1640-1830 by an authorized administrator of Digital Commons @ University of South Florida. For more information, please contact digitalcommons@usf.edu. 
The Experience of Domestic Service for Women in Early Modern London, ed. by Paula Humfrey

\author{
Keywords \\ domestic service, employment, labor, legal documents \\ Creative Commons License \\ (c) (i) $\Theta$
}

This work is licensed under a Creative Commons Attribution-No Derivative Works 3.0 License. 
Paula Humfrey, ed. The Experiences of Domestic Service for Women in Early Modern London. Burlington, VT: Ashgate, 2011. \$99.95. 218pp. ISBN 978-0-7546-6155-9.

Reviewed by Marisa Iglesias, University of South Florida

The servant/master relationship that attracted eighteenth-century readers in Samuel Richardson's Pamela, or Virtue Rewarded continues to fascinate society today as the success of Kathryn Stockett's The Help demonstrates. In The Experiences of Domestic Service for Women in Early Modern London, Paula Humfrey captures this interest between the seemingly straightforward division of the superior and inferior and offers insight into the lives of female domestic servants. Though repeatedly portrayed in literature, or addressed in conduct books, servants rarely represent, or speak for, themselves. Humfrey rightly notes that past historians have had to rely on the views of servants offered by the employer classes, and the material in her collection challenges this tradition. Through the legal documents presented in this volume, Humfrey aims to change the accepted narrative that suggests female domestic servants did little to build London's economic infrastructure and instead argues that London's early modern female servants contributed markedly to the urban economy.

Building on D.A. Kent's study that views female servants as "independently moving strands" in the "closely woven . . . fabric of urban life" (26), Humfrey emphasizes the importance of female servants' mobility and independence in the metropolis, themes she views as "central to understanding not only gender history but also labor, economic, and social history more broadly" (25). Humfrey blames the lack of women's occupational data for removing them "from the discussion of England's economy in the early modern period...." (27), an omission that her collection works to correct.

In her key introduction, Humfrey systematically challenges the historiographical assumptions that (1) "[D]omestic service constituted a life stage rather than a working life"; and (2) "[S]ervants were increasingly women who performed work that had no economic value and that remained outside the realm of measurable industrial activity" (26). "The documents," she argues, "suggest that female servants in London could also rely on service as a means of getting income throughout their adult lives despite social strictures against their so doing" (27). Humfrey's evidence also shatters the common belief that female domestic servants were single, unmarried, and childless. Her carefully collected material shows a different demographic_-one that includes women of various ages and marital statuses.

Depositions from the London Court of Arches spanning from 1667 to 1735 comprise over a third of the volume. Humfrey includes all cases in which female domestic servants testified about their own lives or that of their employers (30). Overwhelmingly, servants appear to be brought in for cases of divorce (separation) or defamation charges, supporting that "what the servants knew" is sizable. The final chapters in the volume contain female servants' settlement examinations for the parish of St Margaret Westminster from 1718 to 1735, chosen for "the social and economic diversity of its inhabitants" (153). According to Humfrey, servants sought settlement as a form of security, to counteract the instability and insecurity of their employment. To build a complete picture, Humfrey presents the records in full because she "see[s] in them something 
revolutionary and rare: they are texts that reveal details of laboring women's paid work in a period of the past when no explanatory categories for women's waged work existed" (34). In addition to marital status and wages, the examination records show the servants' geographical and social mobility, supporting Humfrey's conclusions.

The material presented in this volume shifts the traditional view of the early modern city_ “one in which patriarchy was a constant and stable institution, women knew their place, and the world had not yet tipped into the chaos that would come to define urban modernity" (1).

Female domestics, instead, showed independence, mobility, and agency. Utilizing contractual work throughout their adult lives, these women, Humfrey concludes, "held a degree of agency that took them well beyond the prescribed ambit for early modern women in civic life" (1). However, Humfrey also points to the complex position female domestics held. Cultural standards created certain limitations: female servants performed wifely duties while acting as contract employees. The sources in this volume support the position that female servants may have used service as a way to gain and maintain independence. Yet, work was only available "to women who successfully protected and defended their reputations for virtue" (29). Humfrey shows that in this way, these women both found themselves upholding traditional values while forging new paths.

Humfrey spends considerable space defining domestic service. The lack of a fixed definition is important, she argues, because "it is the gaps between descriptors that allowed domestic service for women to arise as a unique form of wage labour in late seventeenth and early eighteenthcentury London" (7). The text that outlined legislation concerning servants until the start of the nineteenth century, The Tudor Statute of Artificers, specified three categories: "servants in husbandry (yearly hires); artificers and workmen (hired for varying periods); and day laborers" (10). These categories, Humfrey points out, fail to accurately define domestic servants, and as such they found themselves excluded from many of the statutes that addressed master servant relationships (11).

The prefatory material provided by Humfrey before each deposition provides a brief summation of each case and frequently includes "bonus" information on early modern culture. For example, in the case of Hubbard $v$ Hubbard, readers learn that periwigs became fashionable in London after Louis XIII wore one because he was prematurely balding (53), and in the divorce case, Citty $v$ Citty, domestic servant Margaret Roach was asked by her employer to "search his wife and see if she was not a witch" referring to the practice of searching a woman for a mole or blemish that could be used as a sign of a "witch's teat" or "[D]evil's mark," a practice that was frequently used in the $16^{\text {th }}$-century (62).

Humfrey acknowledges the potential limitations of the depositions, addressing "what Lawrence Stone has called " "opposite fictions" in their testimonies: partial truths constructed to further the respective parties' agendas" (31). And to this possible problem, she gracefully suggests that all texts "must make sufficient contact with the world of their time to be intelligible to their readers" (31). Like all documents these texts tell much about the time and place in which they originated. Although Humfrey introduces each law suit well, we unfortunately do not discover the cases' outcomes, though I freely acknowledge that doing so would not further her purpose, but only feed my curiosity. The most impressive aspect of Humfrey's collection is the lack of a singular 
argumentative standpoint. Instead, the documents gathered here display many avenues of interpretation-all worthy of further study. 